\title{
Framing Childhood: Representations of Children in Gunnar Lundh's Photo Agency Archive
}

\author{
By \\ Helena Hörnfeldt
}

\begin{abstract}
Based on Gunnar Lundh's photographs from the period 1920-1960, this article aims to discuss how a visualisation of children and childhood in cultural history collections can be addressed. This period is known as the time when the Swedish welfare state and society took shape, a period when the conditions for children in society changed in a number of ways. Lundh's photographs are therefore viewed as cultural expressions of an era of cultural, societal and political change in which photographs of children came to play a particularly important role. Some of Lundh's pictures have been reproduced in works about the constructive period of the Swedish welfare state and have thereby had an important role in narrating the story of the welfare society. In this way, Lundh's photographs of children must be understood in the specific context of visual representations of children and childhood from this time period. In the many pictures of children in Lundh's collection, the children play, are dressed up in fine clothes and national costumes, visit the library, pick flowers, play along the shore, etc. The children are depicted both active and passive, innocent, childish and pure. In that sense, the photographs follow a genre-specific way to portray children which was typical at the time and still is. In the article, I argue that an understanding and a specific way of seeing and portraying children and childhood became institutionalised during this period. However, in this institutionalisation process of images of childhood, Lundh's pictures of children seem to reproduce and enhance this "pictorial vocabulary" in many ways that appear natural to childhood.
\end{abstract}

Keywords: Children, Childhoods, Photographic genres, Pictorial vocabulary, Representation, Sweden, Welfare state.

Hörnfeldt, Helena "Framing Childhood: Representations of Children in Gunnar Lundh's Photo Agency Archive.", Culture Unbound, Volume 12, issue 1, 2020: 6589. Published by Linköping University Electronic Press: http://www.cultureunbound. ep.liu.se 


\section{Introduction}

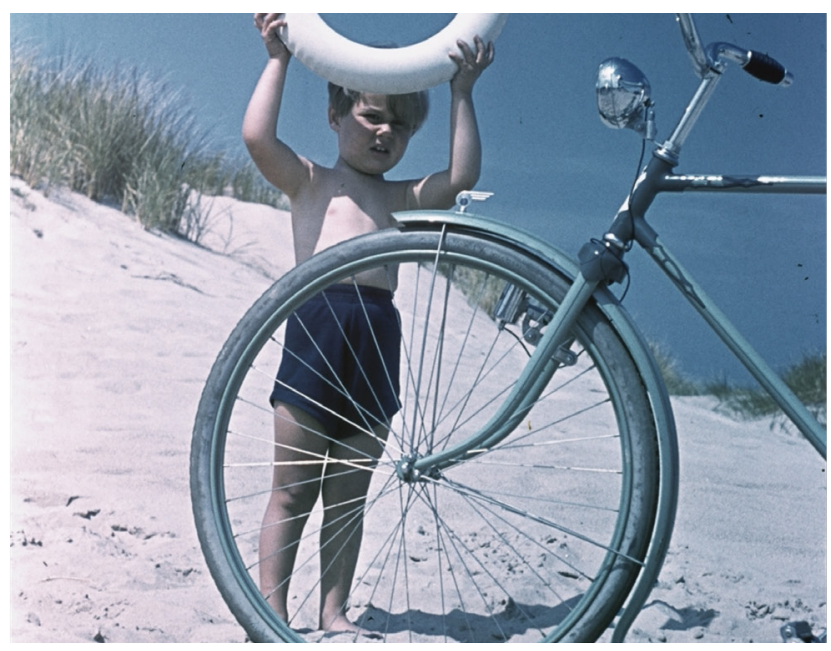

Fig. 1. Child with a swim ring next to a bicycle. Sandy beach, 1940 (NMA.0049367).

A child is standing behind the front wheel of a bicycle, holding a swim ring above their head. ${ }^{1}$ The photo is shot on a beach with white sand dunes in the background. The child looks straight into the camera. By its composition with the bicycle's front wheel in the foreground of the child who appears to be put on display, the picture gives an impression of being artistically designed. The photograph was taken in 1940 by the photographer Gunnar Lundh and is one of several depicting either children and bicycles or children on beaches. The composition in the picture, in which a person is placed behind the front wheel of a bicycle, is a recurring motif in Lundh's collection. So are pictures of carefree, playful and healthy children in outdoor surroundings.

The first pictures of children in Gunnar Lundh's photo collection are from the 1920s. However, most of them are shot during Lund's most productive period between the 1930s to 1950s. ${ }^{2}$ This period is known as the time when the Swedish welfare state and society took shape, a period when the conditions for children in society changed in a number of ways. During the first decades of the 20th century, children gradually became regarded as a specific category with distinctive features and specific needs and rights, such as schooling, leisure and health (cf. Sandin 2003). Parallel to the child-saving movements that gained significant influence in many Western nations in the beginning of the twentieth century, the emotional value of children was augmented (Sandin 2012:62). 
Society's responsibility for, interest in and insight into the lives of children increased significantly during Lundh's productive period. Using new, modern institutions for children and families, such as preschools, child health care centres and social security systems, society was given the opportunity to both control and educate parents and children, and form a modern individuality that could meet the demands of a more complex society (Hörnfeldt 2009:124). The vision was that Swedish society had to reform and disengage from ancient traditions and bad customs (cf. Hirdman 2000:126). The idea of society as a community where solidarity, reason and justice would prevail for everybody is also what came to be summarised in Per Albin Hansson's metaphorical concept of "The People's Home" (Folkhemmet in Swedish). ${ }^{3}$ In this community, all citizens would be entitled to a better home, better food, better education, better care, etc. (cf. Hirdman 2000:90). Pictures of children standing or sitting in front of newly built, modern blocks of apartments, or health care professionals, or mildly monitoring school professionals therefore served as examples to spread what many scholars have referred to as welfare propaganda (see, for example, Jönsson 2011). In that sense, photographs of children served as ideological support for welfare policy on public health and eugenics (Habel 2002). These kinds of commonly occurring visual representations of children were also one of many ways to show the importance of children in correlation with the future of the nation (Hallberg 2017:266 cf. Peacock 2014).

\begin{abstract}
Aim
The article sets out from the standpoint that photographs are cultural expressions. Based on Gunnar Lundh's photographs from the period 1920-1960, this article aims to discuss how a visualisation of children and childhood in cultural history collections can be addressed. These photographs are therefore viewed as cultural expressions of an era of cultural, societal and political change in which photographs of children came to play a particularly important role. To problematise the visual representation of children and the life depicted on the basis of photo-historical material is an overall aim of the article. What stories about children's lives and society's relation to childhood do Gunnar Lundh's pictures tell? In what ways are dominant values, norms and political visions of the nascent welfare state present in Lundh's pictures? How are the children portrayed in the photographs? Are differences in terms of gender, age and ethnicity visible in the pictures? Additionally, the article will explore methodological issues, such as: How are the photographs in the collection related to each other? Is it possible to say something substantial based on only one picture without knowing anything about its origin or the motif? What other sources are needed to understand the photographs and children's terms and conditions of living as exposed in these photographs?
\end{abstract}


Since most of the photographs in Lundh's collection are archived without specific information about motives and approaches, it becomes crucial to understand the context surrounding the photographs. In what setting are they shot? What are the children doing, how are they depicted and what kind of knowledge is possible to obtain through these photographs (cf. Becker, Ekecrantz \& Olsson 2000, Blomberg 2005, Leipe 2001)? Is it, for example, possible to learn something from the photographs about children's lives during the time-period studied? This also raises the question of how these photographs of children talk to other visual representations of children published or circulated during the same timespan. In what sense are Lundh's pictures expressions of genre-specific motives situated in time and place? Another circumstance that can be scrutinised is the relationship between the person taking the picture and the one being photographed. Generally, children relinquish control to the photographer which makes them ideal subjects for the camera (Holland 2004:9). As children are normally in a subordinate position in relation to an adult photographer the question of which subjects that are able to resist being depicted becomes essential.

In addition to what has been said above, it is also interesting to ask why there are, relatively speaking, so many photographs of children in the archive. For what purpose have the photos been taken and filed? One should bear in mind that the photographs in Lundh's photograph agency were intended to finance his and his family's life. These social facts make the issue of whether photographs of children were particularly lucrative during the period interesting and perhaps necessary.

Children's lives and situations are best understood in relation to adults' perceptions and hopes of a certain kind of childhood. Thus, one key question is if it is possible to understand photographs of children at all, without analysing them from an adult-child relational perspective (cf. Alanen 2009)? The pictures might not tell us anything essential about children's lives from the children's own perspectives. Rather, it might be a story of how a normative adult world wanted children to be represented.

\section{Pictures and Processes}

The main material for this article consists of photographs of children from Gunnar Lundh's photo agency archive. Among the 300000 pictures in Gunnar Lundh's commercial photographic archive, there are many photographs of children at different ages. The children in the pictures play, are dressed up, stand in front of and sit in fancy cars, visit the library, wash dishes, pick flowers, play along the shore, etc. Sometimes they are depicted alone, and sometimes with other children or with one or more adults. In connection with certain photos there is 
information added, such as where and when the picture is taken and who the child is. Occasionally, the subjects in the photos are the children of Lundh's close friends whom he visited during his travels around Sweden. Sometimes the people in the photos are his own relatives, as, for example, the pictures of his daughter Jytte (cf. Steinrud in this publication). Lund's private and professional lives thus appear to be almost equally important parts of his archive.

Analysing the photographs, I started by putting them in chronological order. I then selected some recurring themes, such as the innocent child, the playful child, the child in nature and the child as an aesthetic project. These themes also constitute the structure of this article. In the process, I let my previous research on children and childhood during the period of the welfare state's construction in Sweden lead the way (Hörnfeldt 2009, 2015). Therefore, previous studies of this period with a particular focus on visualisation of children in photographs and images have given a comprehensive understanding of how pictures of children were used to communicate political messages (see for example Habel 2011, Hallberg 2017, Higonnet 2013, Jönsson 2011). Some of Lundh's pictures have been reproduced in works about the constructive period of the Swedish welfare state and have thereby had an important role in narrating the story of the welfare society. In this way, Lundh's photographs of children must be understood in the specific context of visual representations of children and childhood from this time period. However, placing this study in the range of previous research on the welfare state is not without problems. The period when the welfare state was constructed has been both accurately and thoroughly researched, although most studies have primarily concerned the discursive level. This has led to a rather undiversified understanding of this specific time period in Swedish history. My own research is no exception in that respect (Hörnfeldt 2009, 2015). Hence, a uniform story about the welfare state has led to a grand narrative of this time-period, which has in turn become more true than the lives actually lived. However, few studies have focused on depicting people's lives (or in this case children's lives) in relation to the great societal transformations that took place. Since this study also mainly concerns a discursive level that Gunnar Lundh's photographs of children convey and construct, there is an imminent risk that the results show what previous research has already shown. With that said, I would like to point out that the interpretations of the photographs and Lundh's archive as a whole have been characterised by an awareness of these matters.

One way to contextualise the photos is, as mentioned above, by reading previous research about historical photographic material on children. In a Swedish context, there is a limited selection of scientific works on photographs of children taken during Lundh's productive period, which occurred during the 1930s to 1950s. In many of the works that deal with this specific epoch in 
Swedish history, pictures of children have rather been used to show how some popular adult education elements formed the welfare state's relationship with the individual. However, one work that served as an inspiration for my interpretations of Lundh's photographs and the discussion about its source-historical value is Mathilda Hallberg's dissertation from 2017, Children on display. Family, Welfare state and Nation in Photo Contests and Photo Books 1930-1944. Hallberg's thesis deals with the same time period as Gunnar Lundh's collection of photographs.

\section{Photographs of Children as Historical Sources}

Within ethnological research, photographs and other images have seldom been used as main sources to understand cultural processes and are therefore not commonly used, except as illustrations. As in historical research, ethnological research has been primarily text-based (cf. Blomberg 2006). On the other hand, many ethnologists have used cameras in their fieldwork, though as an extra eye, perhaps with the primary aim of not forgetting people, artefacts and settings. Nevertheless, the use of images as a basis for analysis is unusual, even though there are some ethnological exceptions. For example, Nils-Arvid Bringéus' book about "Imagelore" (Bildlore) from 1981 (Bringéus 1981), Anja Petersen’s work with photographic portraits (Petersen 2007), Marianne Larsson's dissertation about postal uniforms (2008) and finally Simon Ekström's work about the cultural history of lobsters (Ekström 2017) are some examples of ethnological work that fits into the field of visual cultural history. This field is definitely growing, in addition to other image interpretation disciplines (Petersen 2007:24f), as is the case with ethnology. The historian Eva Blomberg describe this turn as a pictorial turn (Blomberg 2006:37f).

In order to use photographs as historical sources, there is a need to see the pictures and find a way to systematise what we see (cf. Blomberg 2005:266). Photographs have a special quality in that they often evoke emotions in a particular way. Perhaps this especially applies when there are children depicted or when the photographs stir up memories and offer feelings of nostalgia. In general, an image of a child "both creates conceptual meanings and carries a powerful emotional charge" (Holland 2004:2). Photographs, for their part, offer a sense of both reality and illusion since they are simultaneously more representational and fantastic than language and written texts (cf. Holland 2004:6). Photography has an aura of truth and documentation, even though everyone that has been portrayed in a photo knows that there are many things going on behind the scenes that are not obvious in the final result (cf. Olsson 2000). The meaning of photographs is always intimately linked to the layout, captions, context and use (Sekula 2003:445). A photographic image cannot, therefore, be perceived as a mirror of reality but as a construction. 
Photographs have often been regarded as illustrations of the written. However, if the object of study is the photograph itself, there are other considerations that must be taken into account. There are many ways of understanding pictures and also several methods involved in a visual analysis. In my analysis of Lundh's pictures of children, I primarily relate to how photographs make sense and how they are identifiable. Moreover, I am interested in how pictures construct knowledge and knowing (cf. Blomberg 2005:267). Gunnar Lundh's photo collection should likewise be understood as a whole. Analysing only one photograph from a vast image archive means taking it out of its context. Bengt Erik Eriksson and Roger Qvarsell have argued that a compilation of photographs in a photographic archive should be understood as constructed visual narratives aimed at portraying processes of social change (Eriksson \& Qvarsell 2003).

Accordingly, to study historical photographs of children requires an interpretation of the exposed subject based on how it appears in relation to the context. Describing how children are portrayed in the photos therefore becomes the central task.

\section{Children as a Historical Category}

To write about children in the past is difficult since the children's own voices are rarely documented. Children as physical beings, and childhood as a concept, have existed as a phenomenon in society throughout history, even though the meaning of childhood has changed. In the archives, however, children's voices are partially silent and invisible. Before I elaborate more on the epistemological and methodological issues concerning the study of children and childhood in the past, a discussion about the category of children in general is needed. How is it possible to know when the historical photograph is depicting a child? Or, phrased differently: How is a child recognisable in photographs?

Firstly, the category of children holds everything from an infant to an almost full-grown 18-year-old. The fact that the variation is great may not, however, be that strange. Age is not always synonymous with chronological age; we also have a biological age, phenotypic (appearance) age, and intellectually can we discuss mental age. In addition to these parameters, it is not uncommon to achieve a social age by demonstrating certain skills. As a result, many childhood researchers have claimed that children as a category is culturally constructed and any definition of what a child is therefore contradicts itself (see, for example, Fahlander 2011:29). There are, nevertheless, certain general factors and characteristics that usually differentiate children from adults, such as size, appearance, clothing, dependence, practical and social experience, etc., even though these factors are always situated 
in time and place (cf. Cunningham 2006:13). However, in order to recognise childhood, children are surrounded by attributes such as special children's clothing, toys and things that recreate leisure and play. These attributes, for the most part, also signal non-productivity and innocence (Hörnfeldt 2009:99).

Children are placed in a 'non-adult' category and therefore not thought of as citizens, gendered and sexual beings-in some cases they even stand somewhere between animals and humans. It makes the category very interesting to discuss in order to better understand general questions about social structure and ideology in a given time and place (Fahlander 2011:7). Still, there are obvious differences, for example, between how girls and boys are portrayed in Lundh's photographs. For this reason, it is crucial to ask the question how the children are depicted in relation to age, ethnicity, sex and class.

What is mostly preserved in the folk life archives is adults' memories of their childhood and other sources that reveal society's understanding of what a child is (cf. Hyltén Cavallius \& Fernstål, in this publication). Gayatri Spivak's (1998) concept of the 'subaltern' is sometimes used to describe children, since it is seldomly children's own thoughts and understandings that are heard (cf. Fahlander 2011:5). As a subaltern is a subject whose voice does not have any space in the general discourse, adults are the ones who define what a child is and what a childhood should be, regardless of whether it is a matter of past or present (cf. Cunningham 2006). To give children their own voice has therefore become both a starting point and a goal in modern childhood research.

Another issue when studying children and childhood in the past concerns how the subject of childhood has often been ignored and trivialised. It is not until recent decades that childhood studies have raised the issue of how childhood has been overlooked or dismissed in history studies. Just as class, gender and race have challenged academic disciplines, the subject of generation is now raising the same challenges (cf. Alanen 2009, Higonnet 2002:200). Nevertheless, the Swedish research on children's history is, as the historian Susanna Hedenborg writes, confusingly small (Hedenborg 2018 (2005:9). Hedenborg reflects on this gap and poses the question of whether this has to do with children's lack of power in society or if the answer has to do with research about children rarely being connected with high scientific status. Since children are seldom described in historical sources, one reason for the silence of interpretations of childhood in the past could be that the primary sources are too few to provide a basis for new knowledge about children.

Although the children's own voices from the time period 1920-1960 seem difficult to reach, photographs taken of children during this period were popular. Gunnar Lundh was undoubtedly not alone in focusing on children in his photos. Hallberg writes that the culture of visual display and the growth of the welfare 
state and the "modern project" are closely linked together. Films and pictures of children have, for example, been emphasised as tools with which to communicate ideological support for political messages (Hallberg 2017:15, 266, cf. Habel 2002). The representations of children became tools in the formation of society. The practice of using children as photographic motifs in the social debate was however not solely a Swedish phenomenon. Visual representations of children were, for example, an important part of the construction of national ideals in both Soviet and Nazi propaganda (Peacock 2014, cf. Hallberg 2017:15).

As previously mentioned, the time when Gunnar Lundh was active as a photographer was a time when children's lives and conditions changed fundamentally. At the end of the 1920s, there was at the same time both a strong optimism about the future and concern about the children of society. The reason for concern in the late 19th century were the ideas that children should be saved from the effects of inhumane industrialisation, where they grew up in unsightly homes, lacked nutrition and care and drifted around in the city's damaging environment (Cunningham 1991, Sandin 2003:225). The decades after the turn of the century were characterised by a kind of conceptual struggle over the interpretations and meanings of children and childhood. This struggle also meant that children became visible as political objects in a different way than before. It is in this context that the photographs of children in Gunnar Lundh's photographic collection must be understood.

\section{The Innocent Child}

When writing about children in the past one must consider how children are often assumed to have been an exposed, exploited and affected category. This politically useful mantra has been fundamental in how children have been depicted, read and interpreted in historical sources and visual representations. There are certainly many reasons for such a reproduction, perhaps due to popular cultural expressions, such as Dickens' Oliver Twist (1837-39) (Pollock 2002:XVI.). In photos from the eighteenth century and early twentieth century, children are often portrayed as small adults, standing together with their family as parts of an economic and productive unit (see, for example, Reinius 1986, cf. Hallberg 2017). Not infrequently do they look sad and solemn. The children in such photographs are not depicted as essentially different from the adults except that they, due to their height, are strategically placed at the front of the photo. The children do not wear distinguishably different clothing from the adults apart from the fact they are smaller in size.

There is also the tradition of portraying children as innocent, cute and authentic. According to Heywood, the linkage between childhood and innocence 
became ingrained in Western culture, a lasting legacy of the Romantics of the nineteenth century (Heywood 2005/2018:57-58). Yet it was in the medium of photography that these images of a romanticised childhood found their fullest expression (Higonnet 2013:297-298). Art historian Anne Higonnet writes that "romantic childhood needed a medium whose claims to natural innocence and spontaneity were credible as its own. That medium was photography." (Higonnet 2013:301).

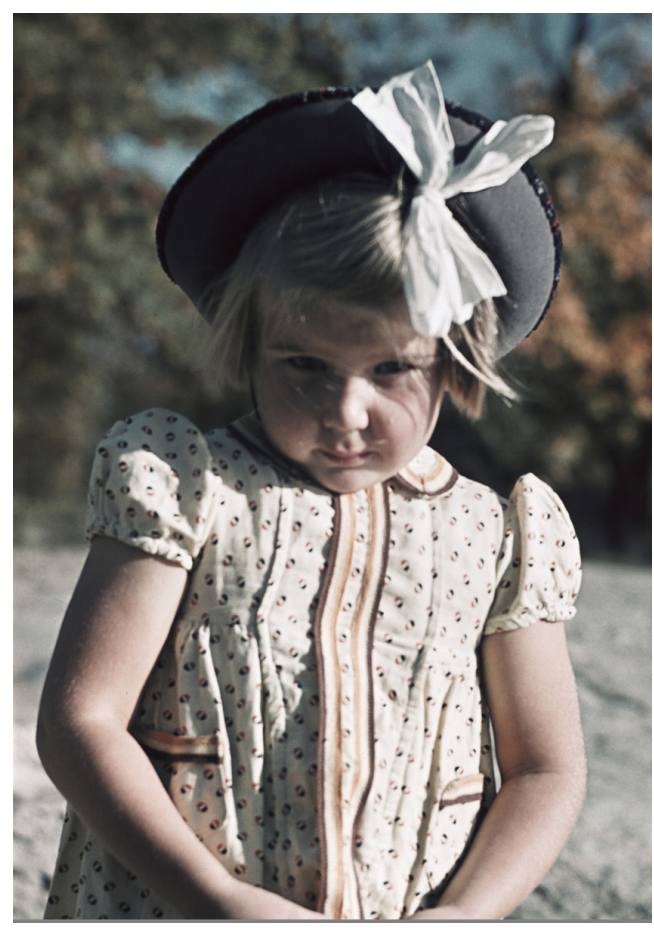

Fig 2. Small child wearing a spotted dress and a hat with a bow, 1941 (NMA.0054487).

However, the idea of the innocent child has several meanings. In the picture above, I see a relatively small child, dressed up in a dress with puff sleeves, a hat and a white ribbon. Moreover, the child is looking with downcast eyes into the camera lens, which gives a vulnerable, almost scared appearance. The shy and grave expression also captures the consciousness of being looked at and the unequal relationship with the adult photographer. If we turn from the child and look at the surroundings, there are some blurry trees with perhaps late season leaves in the background. It also seems like the child is standing on a cliff, possibly close to water. Judging by the balanced relationship between the child's position and the surroundings, the photo looks, like the picture above of the child on the beach, 
arranged and carefully composed compared to many of Lundh's other pictures, which are taken in the moment without any apparent intent of composition.

In addition to the picture itself there is not much information that comes with the photograph, except for the notice of when the picture is taken, namely 1941. The picture has been digitised and is published on the site "Digitalt museum" (Digitised museum) with a short description of the motif. "Little girl wearing a spotted dress and a hat with a bow" (my translation). So, to contextualise the picture it is necessary to search deeper into the archive. What other pictures, for example, are printed on the same contact sheet? Is it possible to acquire more information about the picture when looking at the contact sheets in close relation to this specific one? Are they sorted chronologically? After finding the contact sheet with the photo of the child above, I studied the adjoining contact sheets more carefully. First of all, it appeared that the photograph is a diapositive and that the contact sheets are chronologically organised. On this specific sheet there is one more photo of the same child, standing in the same spot but looking upwards rather than straight into the camera. There is no written information about where the photo is taken, who the child is or why Lundh has chosen to take the picture. The other photographs on the same contact sheet portray two different adult women, one standing with a book in front of a bookshelf and the other in different outdoor settings: in front of a pond, on the staircase to an older house and leaning against a birch tree. The women are both well-dressed; the second woman is wearing high heels, a checked dress, hat and overcoat. At the bottom of the same contact sheet there is a series of photographs of two and three women in folk costumes standing in front of a traditional Swedish fence, behind which there are some cows. Since the large number of photographs of the woman in the checked dress depict her in different poses in front of various trees on which the leaves change in colours, one could assume that these pictures are taken during early autumn. In addition, based on the clothes that both the women and the child are wearing, it is obvious that there are no real farmers or occupied farmhouses depicted in the pictures. Rather, as I started to recognise places and buildings represented on the contact sheets, I became convinced that these photographs are taken at the open-air museum Skansen in the centre of Stockholm. In addition, after my review of most of Lundh's many contact sheets, it is apparent that Skansen is one of his more frequently used photo sites, even generating a category of its own in his archive. The contact sheet in which the photographs of the child with the spotted dress are printed on is thus one of many with similar motifs in Lundh's photographic archive. Skansen is a place many Swedes have visited during holidays and leisure time for the purpose of walking, enjoying the old Sweden and watching Nordic animals. Skansen is thus also a typical place for photography in general. In addition, Skansen is a place that has a strong national symbolic 
value where Swedish history, traditions and nature are embodied in one place. Therefore, it has an aura of a lost Sweden in which people lived close to nature and animals. A lifestyle that was at the time and still is associated with the idea of an ideal childhood. Hallberg writes that Skansen is presented in the photobook "Svenska barn i bild" (Images of Swedish Children) ${ }^{4}$ as a special, culturally significant place for children where they are offered an experience of a traditional agrarian lifestyle and a childhood with proximity to animals and nature (Hallberg 2017:234). Thus, an experience that contrasts with the dirty and unhealthy urban life of industrialisation and modernisation. Within this context, the dressed-up child in the photo becomes more contextualised and comprehensible.

As shown in my interpretative description of the photograph above, the child looks shy and almost grave. There are several signs in the photograph, such as the dress, the white ribbon and the appearance of the child that leads the mind towards the thought of a girl. Equally important, it is hard not to notice and sense the cuteness in the picture. Perhaps the most common perception of children's 'being' is characterised by innocence, spontaneity, naturalness and honesty, which is put in contrast to the cultured adult individual (Holland 2004). Compared to the photographs of the adult women on the same contact sheet, the assumed girl appears to be significantly less aware, in that she does not pose or make herself look beautiful in front of the camera. Rather, she is portrayed as physically charming, but not intentionally (cf. Higonnet 1998:71). In that sense, the photographic gaze differs between children and adults. Among Lundh's photographs of children, there is a considerable amount that portrays the children in this way: shy, sweet and lovable. Higonnet writes that pictures of childhood, categorically different from adulthood, first appeared in significant numbers in mid-eighteenth-century British portraits. British painters introduced the vision of a disembodied childhood, a cute childhood, a miniaturised childhood (Higonnet 2013:298). Curator of nineteenth-century photographs (department of photographs at the National Gallery of Art, Washington) Diane Waggoner also claims that photographs of Alice Liddell and other children in the 1850s to 1860s by Charles Lutwidge Dodgson (known as Lewis Carroll) marks a crucial historical moment in the history of modern childhood. "Just as Alice's Adventures in Wonderland transformed the genre of children's literature, Dodgson's photographs established new visual parameters for the representation of children that articulate a historical concept of the self-predicated upon an explicit differentiation of children from adults" (Waggoner 2002:149). Among Lundh's photographs of children, there are some that definitely portray children in this intertextual manner: the innocent and authentic, natural and pure, only aware of the present moment (cf. Holland 2004:9). 


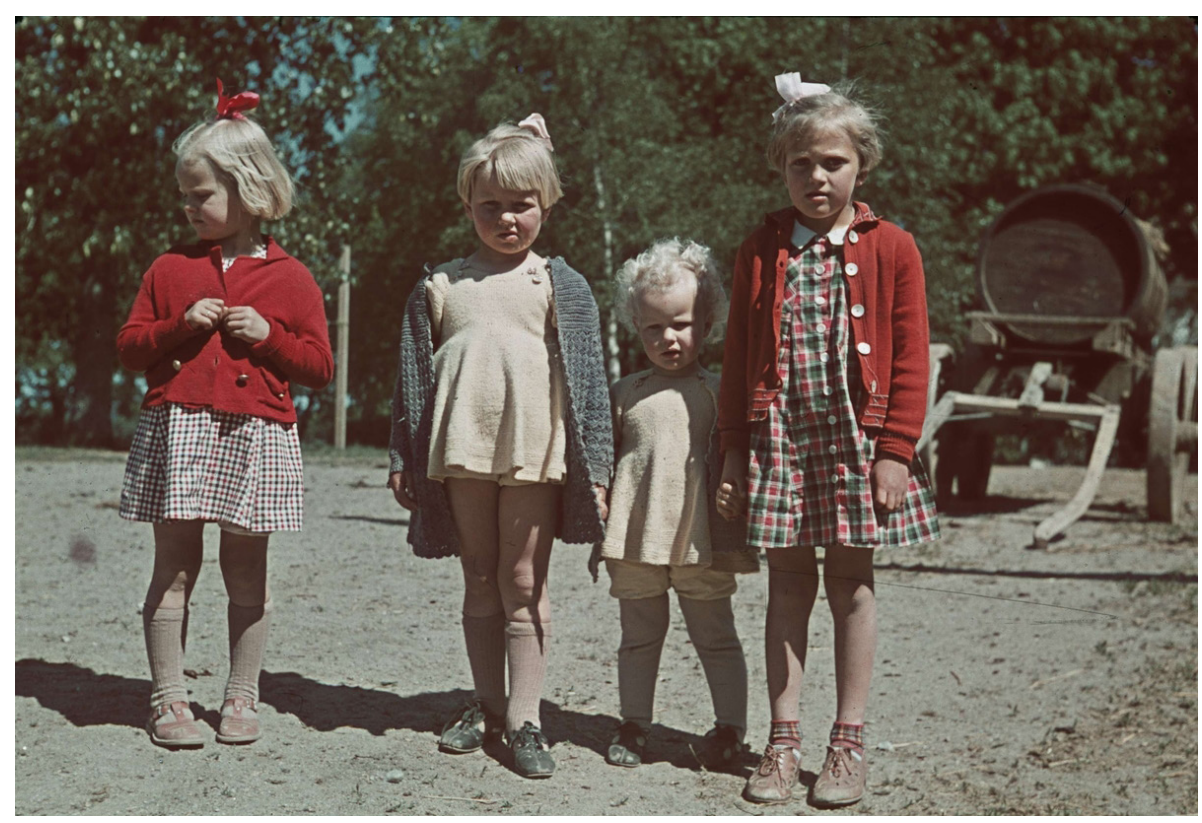

Fig 3. Four children dressed in summer dresses, 1941 (NMA.0050196).

As mentioned above, the constructed idea of the innocent child has several meanings. Since many of Lundh's photographs of children were taken during or in close association with World War II, it is not far-fetched to understand the great interest in photographs of children as a way to offer the people and the nation a great hope for the future. The children represented and acted as symbols of innocence and purity in contrast to the war, the dirty city and industrialisation as such. At the same time, they embodied hope and confidence in the future at a time when everything else appeared fluid and dystopic. Lundh's many photographs of children are therefore not the only ones during this period. As Mathilda Hallberg has shown in her dissertation, Children on display, the interest in photographic representations of children was (and in many ways still is) immense, especially with regard to showing how the life of children ought to be in the modern welfare society. During the years 1930-1944, pictures of children were published in photo contests and photo books. The period between the 1930s and 1940s is a turning point in children's lives in society and the perception of childhood. According to Anne-Li Lindgren, social reform, institutionalised childcare and the growth of education had a significant impact on children's position in relation to the state (Lindgren 1999, see also Habel 2002). The photobooks presented, both in pictures and captions, a unified message which said that more and better children were needed if the nation was to have any chance of competing with other countries in the future. The pictures of children therefore served as tools to communicate 
political messages (Hallberg 2017:15, 88, 266, cf. Jönsson 2011). In addition, the pictures of children also worked as a means of unification for the nation as a whole. Since the future of the nation belonged to the children, the children were the ones who would take the nation into modernity.

\section{Framing Childishness}

A number of the photos in the collection show children in everyday situations. Furthermore, there are many pictures in Lundh's photo collection that depict children performing activities, for example bicycling and skating, as in the photograph below. In this sense, the photographs in Lundh's collection follow a genre-specific way to portray children (cf. Holland 2004). One theme recurrently featured in this genre is the portrayal of people who do something. The children are active. In comparison with earlier photographs of children, it is the vivid moments of everyday life that Lundh portrays and preserves (see for example Reinius 1986). The photographic moment thus does not entail a temporary interruption. This way of documenting and representing children (and adults) can be related to how people were portrayed before the small-screen camera's (in Lundh's case the Leica) entry into the professional life of the photographer. However, these new ways of portraying children also tell us something more than that new opportunities arose with the technical development of the camera. It is also about genre and societal power relations.

The British historian of child images Patricia Holland writes that during the first half of the twentieth century, it was typical of the progressive pedagogy to portray children as active and engaged, and the children were also in the foreground, and not the professionals or the adults (Holland 2004:80ff). It is, however, important to consider that the children were not portrayed as competent subjects, but rather captured through the professional gaze. Holland also points out that many photographs of children from the 1960s and 1970s showed children as energetic subjects fulfilling their childishness and learning at the same time (Holland 2004:82).

In taking a closer look at Lundh's pictures, apart from the fact that many children in general are active, there is a difference between the photographs of girls and boys. Boys are generally more active and playful in the photographs and often pictured along with bicycles, agricultural tools and other activity-promoting tools. The girls, on the other hand, are more often portrayed motionless in front of the photographer as if they are modelled: cute and attractive (cf. Holland 2004). There are some exceptions in the collection, but these are relatively few on the whole. Thus, many of Lundh's photographs of children show a polarised understanding of boys as contest-oriented and playful while the girls are portrayed as submissive 
and pleasing (cf. Heywood 2018:71). However, it is important to emphasise that the age of the child affects this. In general, small children regardless of gender appear in Lundh's pictures as cute, innocent and in a sense passive. Perhaps this can partly be attributed to practical difficulties in directing small children to perform in accordance to the photographers' vision and wishes. Letting the child sit still in front of the camera could have been the only opportunity to capture the child in the picture.

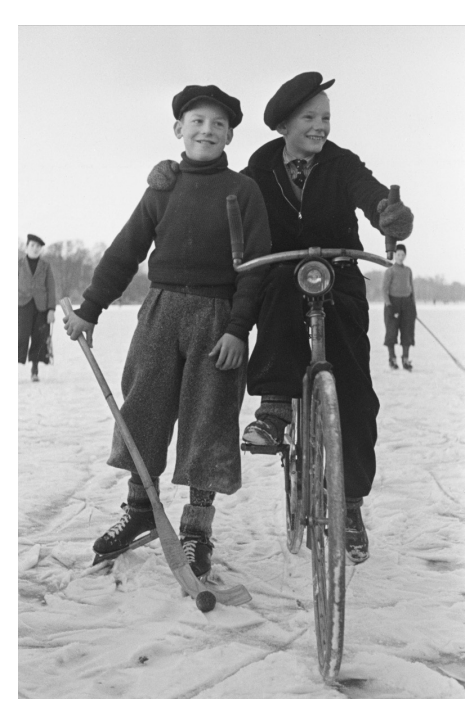

Fig 4. Two children on the ice. One skates and the other cycles, estimated time period 1935-1945 (NMA.0036071).

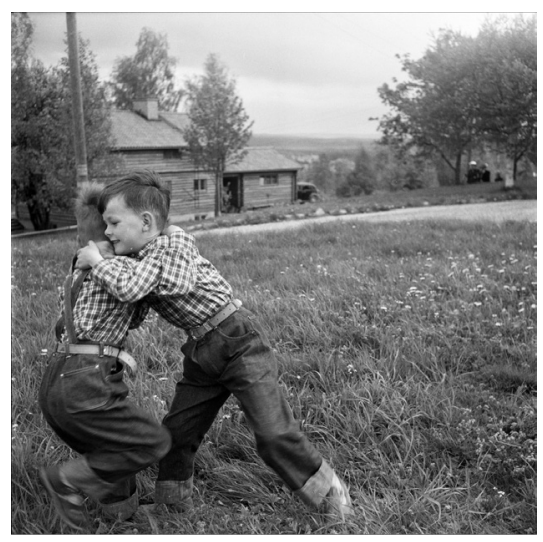

Fig 5. Two children in checked shirts and folded jeans are playing in the countryside, 1952 (NMA.0040872).

In the era of "the People's Home", it was of great importance to document children's play in photographs (cf. Hallberg 2017:195). In a photo series of a newly built housing complex constructed by HSB (a Swedish cooperative housing organisation started in 1923), which Lundh shot in 1934, a large portion of the pictures show special nurseries or kindergartens which were called "playschools". The archives demonstrate that Lundh visited several of these as there are eight playschools in Stockholm documented by him. In the beginning, these playschools, which developed into what is today called preschools, were built at the top of the relatively tall apartment buildings. The idea was that the children should be kept away from the exhaust gases of the streets and get as close as possible to the sun and the light. The playschools were a combination of kindergarten, day care and after-school centre to which every child who lived in the neighbourhood was welcome. The 


\section{Culture Unbound}

Journal of Current Cultural Research

HSB houses were built for workers and lower officials who previously had to leave their children at so-called children's cribs, which had acquired a bad reputation due to their lack of both financial resources and an educational focus (Bjurman \& Henschen 1990:203).

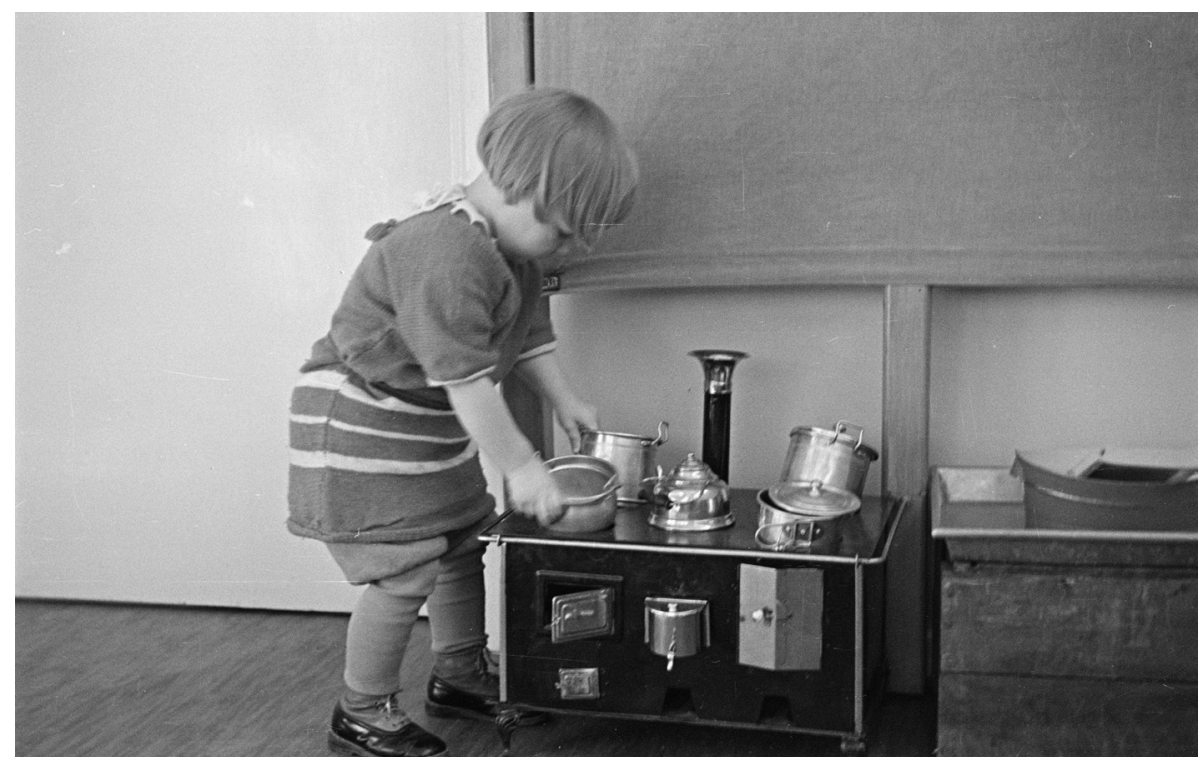

Fig 6. Child plays with kitchenware and stove, 1934, The HSB-housing at Skeppargatan, Stockholm (NMA.0082119).

In the pictures from the HSB "playschools", the children sleep, listen to fairy tales, sing songs, eat and play with toys specially designed for children. These included small stoves and crockery, rocking horses, cars, dolls, blocks, etc. The children look overwhelmingly satisfied and happy, even though some of them are sad and crying. Moreover, since the photographs are in a series, there are also some pictures that show the children being comforted by the professionals. There was thus a reason to also show the caring qualities of the professionals. Nevertheless, the pictures give an overall impression of a happy and meaningful existence at these new, bright, modern and child-centred playschools. We cannot know for certain, but Lundh probably took all these photos on order from HSB. The purpose was most likely to document the revolutionary and progressive ideas with child-adapted spaces and specially developed play tools for children.

To picture children as playful and childish, as Lundh's intentions seem to have been, should also be understood in the light of the idea of saving children from the inhumane older society in which children had to work in dangerous and damaging environments. Play is furthermore the antithesis of work and seriousness, which 
should also be related to the relatively recent ban on child labour at the time and discussions about child labour that had been going on for decades in Sweden and abroad (Sandin 2003).

\section{The Child in Nature}

In connection with the breakthrough of amateur photography in the late 1800s, children became, as mentioned earlier, popular motifs (Hallberg 2017:60). With new standards for composition and the pursuit of naturalness and movement in the picture, children embodied the idea of the natural and undecided that the amateur photographer wanted to capture with his camera (Dahlgren 2013:67ff). In addition, the small, handy camera gave the photographer an opportunity to catch the fleeting moment.

A large proportion of Lundh's photos of children show them in close contact with nature. The children are playing in the sand; they are lying on a flowerbed; they are skiing; or they are just posing with a tree or a rock and so on. The photographs convey a representation of nature as good and healthy: good in terms of space for fun and activities like bathing, running and nudity. Nature is also good in that it offers a selection of goodies like flowers, blueberries, apples, lingonberries and mushrooms. According to other research about photographs of children during the time when Lundh was active as a photographer, nature plays a significant role (Hallberg 2017:150). As the Swedish childhood researcher Gunilla Halldén writes, childhood and nature are linked to each other in an idea where nature is considered good for children and where children feel good being in nature (Halldén 2009). Equally important is the fact that many families, especially the working-class families in the cities, lived in overcrowded conditions, which both encouraged and forced the children to go outdoors. Influential debaters such as Alva Myrdal argued for the need of meaningful activities for children (Myrdal 1935). For the municipalities, this meant investing in play activities, playgrounds and outdoor activities in the city's parks and green areas (Hallberg 2017:189).

The fact that many of Lundh's photographs of children are taken during summer and winter, often outdoors surrounded by nature, is no coincidence (cf. Hallberg 2017:227). During the years 1929-1960, nature had a symbolic significance, especially with regard to children. At first, since the ideological concept of welfare was based on a strong conviction that modern society had to be inhabited by strong, healthy citizens, being outdoor in the fresh-aired nature became synonymous to this ideal (cf. Larsson, in this publication). Secondly, the close connection between children and nature has a long history. The idea of childhood and nature is derived from the romantic 19th-century tradition, which is found internationally but which is also considered to be particularly strong in 


\section{Culture Unbound}

Journal of Current Cultural Research

the Nordic childhood construction (Hedenborg 2018:307). Children are seen as closer to nature because of their status as not yet fully socialised and, in a sense, they are wilder and purer than adults. Analogously, children's closeness to nature has to do with their dynamic, rather than static, characteristics (cf. Aronsson \& Sandin 1996:194).

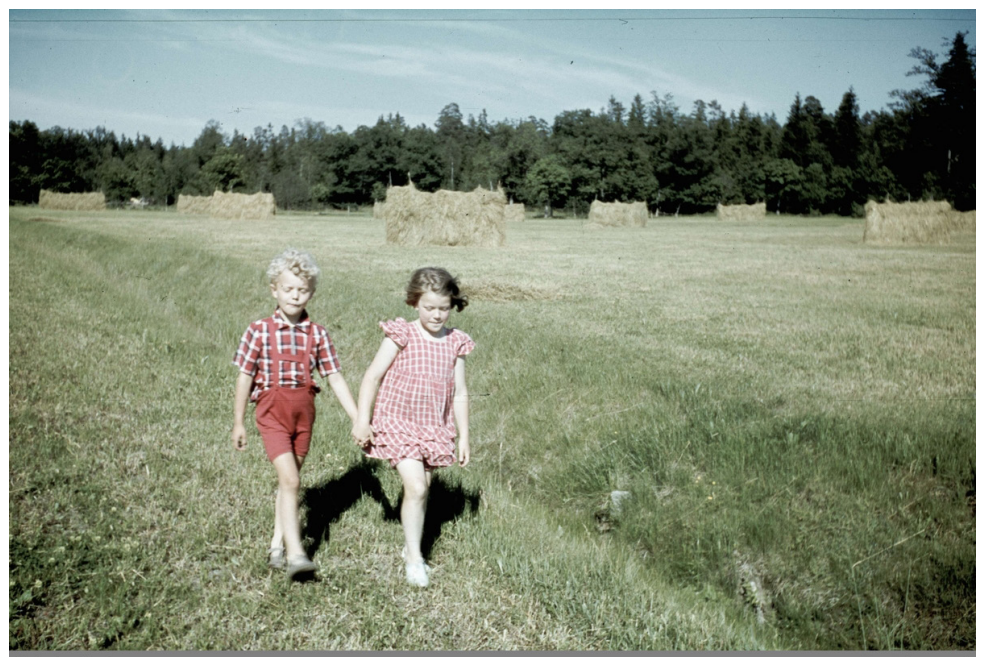

Fig. 7. Two children holding hands in a field, year unknown (NMA.0041759).

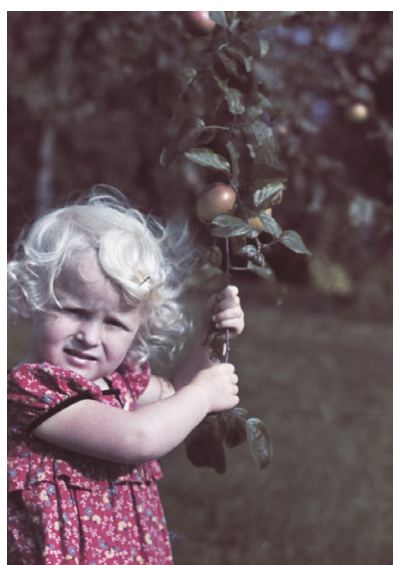

Fig. 8. Small child with floral dress holding a branch with apples 1942 (NMA.0061511).

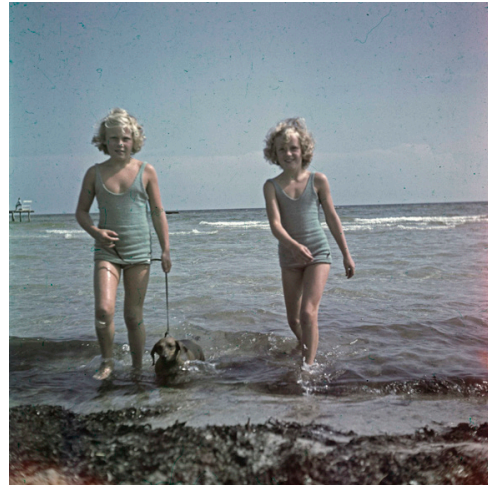

Fig. 9. Two children in swimsuits with a dog on a beach, estimated time-period 1948-1950, Skåne (NMA.0094983). 
The pictures showing children in close relation to nature and the city's organised playgrounds in Lundh's collection are closely connected with other visual representations from the same time period. In the photobook "Svenska barn i bild" from 1942, the state-run playgrounds in the cities are, for example, in focus (cf. Hallberg 2017:191).

\section{The Child as an Aesthetic Project}

The photographs of bathing children in the summer, playful children in sunny playgrounds, and the coherent story of healthy and well-nourished children in Lundh's photo collection must be read in contrast to other images of children and childhood: that of the poor, sickly, undernourished child that occurred in the philanthropic propaganda of the early twentieth century (Aronsson \& Sandin 1996:189). However, this image genre is not completely absent in Lundh's photo collection. There are clear traces of the ideal to depict children as vulnerable and exploited in Lundh's early photographs. This is also something that continues in Lundh's photographic production, but then it is illustrated by photographs of children with an ethnic origin other than Swedish. Raymond Williams has pointed out that at any point in history there exists 'residual' cultural forms, which linger from a previous age and are concurrent with 'emergent' forms in which new styles develop (Williams 1981, cf. Holland 2004:8f).

In order to contextualise Lundh's pictures, I have, as previously mentioned, studied other pictures and images of children from the same time-period. For example, the widespread and popular so-called photo books from this time have provided some insight. ${ }^{5}$ In the photographs of children during this period there are certain recurring ways of portraying children. The photo books stressed how the children in all their innocence must be protected from various forms of threats. These mainly consisted of the so-called population crisis and World War II. It was also in the light of these crises that the relationship between children and nation was actualised. In relation to the threats, children were positioned as national symbols and as expressions of a strong and viable Sweden (cf. Hallberg 2017: 222-223). Together with Billy Ehn and Jonas Frykman, the ethnologist Orvar Löfgren describes the emergence of a welfare nationalism that was largely about bridging class contradictions and an equalisation of class divisions. The state's responsibility was to take good care of all children (and all citizens). In that sense, the nation became part of a larger democratic project, where a healthy body, a functional home and nature were typically given as Swedish signatures (Ehn, Frykman \& Löfgren 1993). 


\section{Culture Unbound}

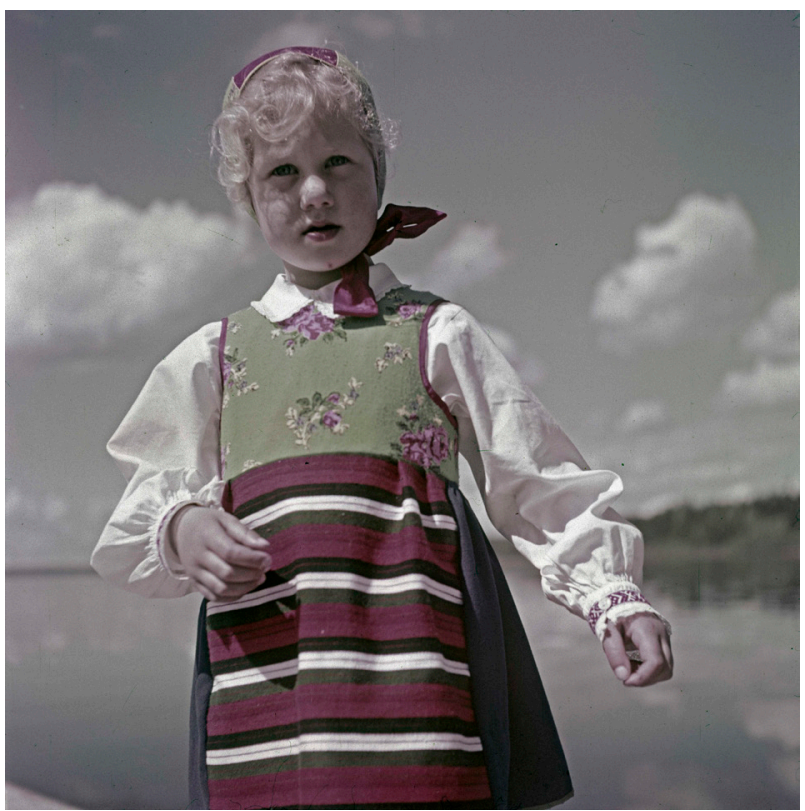

Fig. 10. Child in national costume, 1952, Rättvik (NMA.0094992).

Looking at the whole of Gunnar Lundh's photographs of children, it is obvious that he was influenced by this nationalistic project. Many photographs are taken in an idyllic and romanticised environment, such as Skansen and more authentic rural environments. In his collection there are several pictures where both children and adults are dressed in traditional Swedish regional costumes, as in the photo above. In the photo books mentioned above there are many pictures of children, especially girls, wearing "folk costumes". Hallberg writes that children in folk costumes visualise ideas about kinship and folk culture, and these representations serve as tools in the construction of national identity (Hallberg 2017: 232).

The photographs of happy, active and healthy children in close relation to both nature and the nation were central to the construction of the new modern society in which the children acted as symbols of the future. The art historian Jeff Werner shows how artistic images of light or white bodies in scenic surroundings become meaningful by representing something specifically Swedish. Werner argues that it is through these visual codes that we learn to recognise what is Swedish and what is not (Werner 2014).

Although this description and interpretation of Lund's photographic archive is reliable in many respects, it gives an overly unilateral picture that does not match the entire collection. Lundh also took other kinds of pictures, even though they also could be described as typical of the genre images of the "People's Home". 
In the collection there are several pictures of this kind. These include portraits of children in what is described on the contact sheet as a special school for Sami children (in Lundh's description, Lappskola), as well as a facility for so-called delinquent children (in Lundh's description, Vanföreanstalt) and a series of Roma children (in Lundh's description, Zigenare) in different camps.

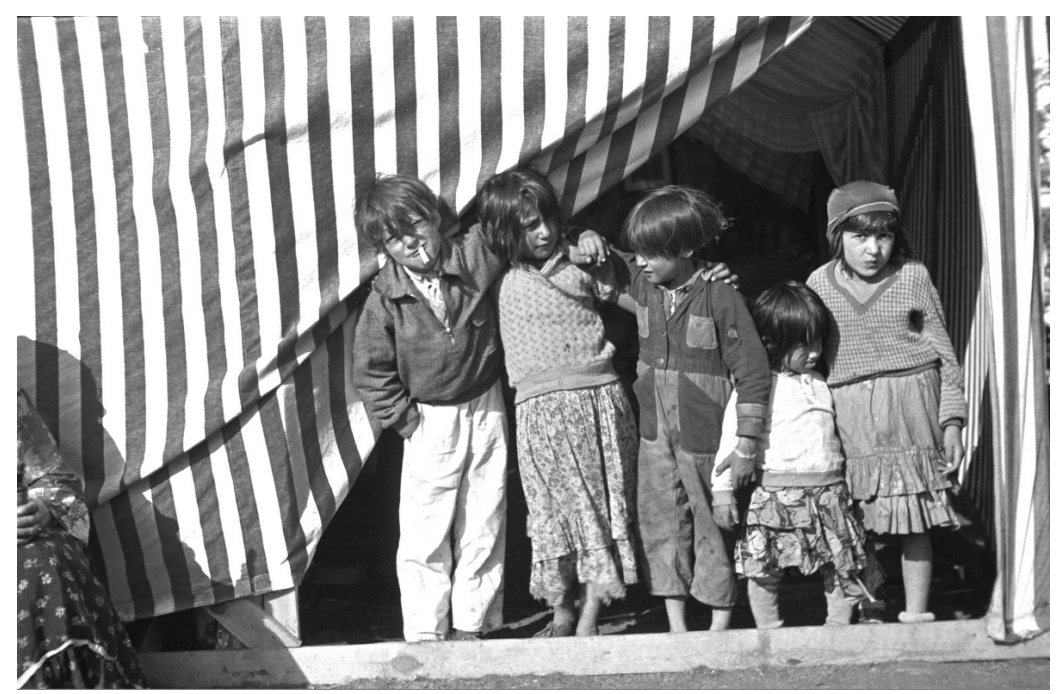

Fig 11. Five Roma children standing in front of a tent. The family Taikon camp, Johanneshov south of Stockholm, 1933 (NMA.0068925).

These photographs convey a different kind of childhood than the one I have shown so far. In these pictures, the children are not portrayed within the same harmonious, idyllic, romanticised and nationalistic frame as many of the other pictures of children. These pictures depict other ways of being a child and other conditions for childhood.

\section{Photographs as Documentary Evidence of their Subjects: Some Concluding Remarks}

The aim to say something essential about children's lives during the time period presented in the beginning of this article seems complicated only by reading the photographs. The widespread assumption that images, especially photographs, reveal what children were and how their lives were lived in the past is highly problematic. The forms and genres in which children and childhood have been represented in the past often overrides the motive for the photograph (Higonnet 2002:201). Based on my review, this is also the case in many of Lundh's pictures of children. Thus, a focus on how images of children were used for political 
and nationalistic purposes should also allow for them to be interpreted as cultural expressions. These expressions differ from traditional historiography by describing the images as neutral and documentary representations of life in Sweden (Strandroth 2009:106, cf. Becker 1992:16).

Hence, since Lundh's photographic collection contains pictures of such different character, including his more private pictures, there is a chance to gain knowledge of a historical childhood that goes beyond the repetitive representativeness of children during the welfare state's construction phase. In addition, his diligent photographing, no matter whether he was on duty or not, and the fact that he saved even the photos of poor quality, gives the archive researcher an overall impression of almost being there.

Many of Lundh's photos of children are taken during summer, winter and leisure time, which gives an overall view of childhood as carefree and happy. Gone are, for example, the serious portraits of working (productive) children who solemnly look right into the camera lens, which were considerably more common around the earlier turn of the century (see Flygare 2004, Lilieqvist 1990, Reinius 1986). From this period, Lundh's productive years and onward, childhood was increasingly portrayed in the fashion we recognise today. An understanding and specific way of seeing and portraying children and childhood became institutionalised during this period. However, in this institutionalisation process of images of childhood, Lundh's pictures of children seem to reproduce and enhance this "pictorial vocabulary" in many ways that appear natural to childhood (Waggoner 2002:150). In that sense, a contemporary resonance of the photographic forms from the constructional period of the welfare state is created here by comparing these pictures with contemporary pictures of children. In addition, the photographs by Lundh, in this case of children, are both recognisable, familiar and -in an ungraspable way-pleasurable. They certainly have an affirmative quality and a nostalgic aura that tells us a story about a society that in many ways has vanished. Through their familiarity and intertextuality, the pictures of children have gained a particular resonance as 'desired images' (cf. Holland 2004:7).

Helena Hörnfeldt is Associate Professor at the Department of Ethnology, History of Religion and Gender Studies at Stockholm University. Her research is focused on childhood studies within ethnology and cultural analysis. She has written on, among other things, children's fears, apocalyptic narratives and humans' affective relations with animals.This article is part of the project Images and Stories of Everyday Life (Vardagens bilder och berättelser), financed by The Royal Swedish Academy of Letters, History and Antiquities, and The Swedish Foundation for Humanities and Social Sciences. Email: helena.hornfeldt@etnologi.su.se 


\section{Culture Unbound}

Journal of Current Cultural Research

\section{Notes}

1 All photographs in the article are taken by Gunnar Lundh.

2 In this article, I use pictures and photographs synonymously. On the other hand, when using the term image, I refer to visual sources in general.

3 Swedish term applied for the concept of the welfare state.

4 The photobook "Svenska barn i bild" (Swedish Children in Images) (1942) was published by the editorial committee for Swedish children in pictures, which was composed of actors engaged in society's child issues (Hallberg 2017:43).

5 The photo books referred to here are: "1000 svenska barn" (1000 Swedish children) from 1930 (published by the newspaper "Svenska Dagbladet" as a result of a photo contest, "The best child image") and "Svenska barn i bild" from 1942 (see above).

\section{References}

Unprinted sources

Gunnar Lundh's photograph archive: contact sheets

\section{Printed sources}

1000 svenska barn (1930): Svenska Dagbladet. Stockholm: Nordisk rotogravyr.

Svenska barn i bild (1942): Redaktionskommittén för Svenska barn i bild,

Stockholm.

Sveriges barn Sveriges framtid (1942): (red.) Bibi Wennberg. Stockholm: IGO-förlag

\section{Literature}

Alanen, Lena (2009): "Generational Order", Qvortrup, Jens, Corsaro, William A. \& Honig, Michael-Sebastian (eds.), The Palgrave handbook of childhood studies, Houndmills, Basingstoke, Hampshire: Palgrave Macmillan.

Aronsson, Karin \& Bengt Sandin (1996): "The Sun Match Boy and plant Metaphors: A Swedish image of a $20^{\text {th }}$-Century Childhood", Philip C. Hwang et. al. (eds.). Images of Childhood. New Jersey: Lawrence Erlbaum Associates.

Becker, Karin (1992): "Picturing Our Past: An Archive Constructs a National Culture", The Journal of American Folklore, 105: 415, 3-18.

Becker, Karin, Ekecrantz, Jan \& Tom, Olsson (2000): "Introduction: Picturing politics in $20^{\text {th }}$ century Sweden", Becker, Karin, Jan Ekecrantz \& Tom Olsson (eds.) Picturing Politics. Visual and Textual Formations of Modernity in the Swedish Press. Stockholms universitet, JMK (Journalistik, medier och kommunikation) Skriftserien 2000:1, 8-25.

Bjurman, Eva Lis \& Helena Henschen, (eds.) (1990): Barn i stan: från sekelskifte till nittiotal, [Ny, rev. uppl.] Stockholm: Folksam.

Blomberg, Eva (2005): "Sätt att se", Historisk Tidskrift 125:2, 263-273.

Blomberg, Eva (2006): Vill ni se en stjärna? Kön, kropp och kläder i Filmjournalen 1919-1953, Lund: Nordic Academic Press.

Bringéus, Nils-Arvid (1981): Bildlore: studiet av folkliga bildbudskap, Stockholm: Gidlund.

Bringéus, Nils-Arvid (2007): Livets högtidsdagar, Stockholm: Carlssons.

Cunningham, Hugh (1991): The Children of the Poor: Representations of Childhood since the Seventeenth Century, Oxford: Blackwell. 


\section{Culture Unbound}

Journal of Current Cultural Research

Cunningham, Hugh (2006): The invention of childhood, London: BBC Books.

Dahlgren, Anna (2013): Ett medium för visuell bildning: kulturhistoriska perspektiv pà fotoalbum 1850-1950. Göteborg: Makadam.

Ehn, Billy, Frykman, Jonas \& Orvar Löfgren (1993): Försvenskningen av Sverige: det nationellas förvandlingar, Stockholm: Natur och kultur.

Ekström, Simon (2017): Humrarna och evigheten: kulturhistoriska essäer om konsumtion, begär och död, Göteborg: Makadam.

Eriksson, Bengt Erik \& Qvarsell, Roger (2003): "Samhället på bild - den tidiga socialvetenskapen och det dokumentära fotografiet", Meeuwisse, Anna \& Swärd, Hans (eds.): Den ocensurerade verkligheten i reportage, bild och undersökningar, Stockholm: Carlsson, 103-120.

Fahlander, Fredrik (2011) (ed.): "Inledning”, Spåren av de små: arkeologiska perspektiv på barn och barndom, Stockholm: Institutionen för arkeologi och antikens kultur.

Flygare, Iréne (2004): "Tre generationer 1900-talsbarn", Sjöberg, Mats (ed.): Jordbrukets barn: barns och ungdomars fostran i agrara miljöer, Stockholm: Nordiska museets förlag, 196-209.

Habel, Ylva (2002): Modern Media, Modern Audiences: Mass Media and Social Engineering in the 1930s Swedish Welfare State, Diss, Stockholm: Aura.

Hallberg, Mathilda (2017): Barn till beskådan. Familj, välfärdsstat och nation i fototävlingar och fotoböcker 1930-1944, Diss, Linköping: Linköping studies in arts and science, No. 713.

Halldén, Gunilla (ed.) (2009): Naturen som symbol för den goda barndomen, Stockholm: Carlssons.

Heywood, Colin (2018/2005): Barndomshistoria, Lund: Studentlitteratur.

Hedenborg, Susanna (2018/2005): Svensk barndomshistoria. Heywood, Colin (ed.): Barndomshistoria, Lund: Studentlitteratur.

Higonnet, Anne (2002): "What do you know about children?" Brown, Marilyn R (ed.): Picturing Children. Constructions od Childhood between Rousseau and Freud, Aldershot: Ashgate.

Higonnet, Anne (2013): "Picturing childhood in the modern west", Fass, Paula S (ed.): The Routledge History of Childhood in the Western World. London: Routledge.

Hirdman, Yvonne (2000/1989): Att lägga livet tillrätta - studier i svensk folkhemspolitik, Stockholm: Carlssons.

Holland, Patricia (2004): Picturing Childhood: The Myth of the Child in Popular Imagery, London: I. B. Tauris.

Hörnfeldt, Helena (2009): Prima barn, helt u.a. Normalisering och utvecklingstänkande i svensk barnhälsovård 1923-2007, Diss, Göteborg/Stockholm: Makadam.

Hörnfeldt, Helena (2015):” Med barnets bästa i fokus - förändrade relationer mellan stat och familj under 1900-talet", Fronesis-Politik. Teori. Kritik, 50-51, 87-96.

Jönsson, Mats (2011): Visuell fostran. Film- och bildverksamheten i Sverige under andra världskriget, Lund: Sekel.

Larsson, Marianne (2008): Uniformella förhandlingar: hierarkier och genusrelationer i Postens kläder 1636-2008, Diss. Stockholm: Nordiska museets förlag.

Leipe, Lena (2001): "Konst som historiskt källmaterial?", Andersson Lars M, Lars Berggren \& Ulf Zander (eds.): Mer än tusen ord. Bilden och de historiska vetenskaperna, Lund: Nordic Academic Press.

Liliequist, Marianne (1991): Nybyggarbarn: barnuppfostran bland nybyggare i Frostvikens, Vilhelmina och Tärna socknar 1850-1920, Diss. Umeå: Univ.

Lindgren, Anne-Li (1999): "Att ha barn med är en god sak": barn, medier och medborgarskap under 1930-talet, Diss. Linköping: Univ.

Myrdal Alva (1935): Stadsbarn. En bok om deras fostran i storbarnkammare, Stockholm: Kooperativa förbundets bokförlag. 


\section{Culture Unbound}

Journal of Current Cultural Research

Olsson, Tom (2000): "Den politiska föreställningen", Becker, Karin, Jan Ekecrantz \& Tom Olsson (eds.) Picturing Politics. Visual and Textual Formations of Modernity in the Swedish Press. Stockholms universitet, JMK (Journalistik, medier och kommunikation) Skriftserien 2000:1, 80-105.

Peacock, Margaret (2014): Innocent Weapons. The Soviet and American Politics of Childhood in the Cold War, Chapel Hill: The University of North Carolina Press.

Petersen, Anja (2007): På visit i verkligheten. Fotografi och kön i slutet av 1800-talet, Brutus Östlings Bokförlag Symposion.

Pollock, Linda A. (2002). "Foreword." Brown, Marilyn R (ed.) Picturing Children. Constructions od Childhood between Rousseau and Freud, Aldershot: Ashgate.

Reinius, Gunnar (1986): Bilder från barndomen, Stockholm: Prisma.

Sandin, Bengt (2003): "Barndomens omvandling - från särart till likart". Sandin, Bengt \& Gunilla Halldén (eds.): Barnets bästa. En antologi om barndomens innebörder och välfärdens organisering, Eslöv: Brutus Östling bokförlag Symposion.

Sandin, Bengt (2012): "More Children of Better Quality. Pricing the Child in the Welfare State", Sparrman, Anna, Bengt Sandin \& Johanna Sjöberg (eds.): Situating Child Consumption. Rethinking Values and Notions of Children, Childhood and Consumption, Lund: Nordic Academic Press.

Sekula, Allan (2003): "Reading an Archive. Photography Between Labour and Capital", Wells, Liz (ed.): The Photography Reader, London/New York: Routledge.

Strandroth, Cecilia (2009): "På forskningsresa i det digitala bildarkivet: ett brukarperspektiv", Dahlgren, Anna \& Pelle Snickars (eds.): I bildarkivet. Om fotografi och digitaliseringens effekter. Kungliga biblioteket: Mediehistoriskt arkiv 13.

Tagg, John (1993): The Burden of Representation. Essays on Photographies and Histories, Minneapolis: University of Minnesota Press.

Waggoner, Diane (2002): "Photographing Childhood: Lewis Carroll and Alice", Brown, Marilyn R (ed.) Picturing Children. Constructions od Childhood between Rousseau and Freud, Aldershot: Ashgate.

Werner, Jeff (2014): "Introduktion". Werner, Jeff \& Björk, Tomas (eds.) Blond och blåögd. Vithet, svenskhet och visuell kultur, Göteborg: Göteborgs konstmuseum.

Williams, Raymond (1981): Culture. London: Fontana. 